\title{
Growth of Salmonella Serovars, Escherichia coli 0157:H7, and Staphylococcus aureus during Thawing of Whole Chicken and Retail Ground Beef Portions at 22 and $30^{\circ} \mathrm{C}$
}

\author{
STEVEN C. INGHAM, ${ }^{1 *}$ RISHI K. WADHERA, ${ }^{1}$ MELODY A. FANSLAU, ${ }^{1}$ AND DENNIS R. BUEGE ${ }^{2}$ \\ ${ }^{1}$ Department of Food Science and ${ }^{2}$ Department of Animal Sciences, University of Wisconsin-Madison, Madison, Wisconsin 53706-1565, USA
}

MS 04-563: Received 15 December 2004/Accepted 14 March 2005

\begin{abstract}
Food regulatory agencies advise against thawing frozen meat and poultry at room temperature. In this study, whole chickens (1,670 g) and ground beef (453 and 1,359 g) were inoculated with Salmonella serovars, Escherichia coli O157:H7, and Staphylococcus aureus on the surface (all products) and in the center (ground beef). After freezing at $-20^{\circ} \mathrm{C}$ for $24 \mathrm{~h}$, products were thawed at 22 or $30^{\circ} \mathrm{C}$ for $9 \mathrm{~h}$. Pathogen growth was predicted using product time and temperature data and growth values from the U.S. Department of Agriculture Agricultural Research Service Pathogen Modeling Program 7.0 predictive models of pathogen growth. No pathogen growth was predicted for whole chicken or 1,359 $\mathrm{g}$ of ground beef thawed at $30^{\circ} \mathrm{C}$ or $453 \mathrm{~g}$ of ground beef thawed at $22^{\circ} \mathrm{C}$. Growth ( $\leq 5$ generations) was predicted for $453 \mathrm{~g}$ of ground beef at $30^{\circ} \mathrm{C}$. Inoculation study data corroborated the predictions. No growth occurred on whole chickens or 1,359-g portions of ground beef thawed at $30^{\circ} \mathrm{C}$ for $9 \mathrm{~h}$. Pathogen numbers increased an average of 0.2 to $0.5 \mathrm{log}$ on the surface of 453 -g ground beef portions thawed for $9 \mathrm{~h}$ at 22 or $30^{\circ} \mathrm{C}$. Our results suggest that thawing $\geq 1,670 \mathrm{~g}$ of whole chicken at $\leq 30^{\circ} \mathrm{C}$ for $\leq 9 \mathrm{~h}$ and thawing $>453 \mathrm{~g}$ ground beef portions at $\leq 22^{\circ} \mathrm{C}$ for $\leq 9 \mathrm{~h}$ are not particularly hazardous practices. Thawing smaller portions at higher temperatures and/or for longer times cannot be recommended, however. Use of values derived from the Pathogen Modeling Program 7.0 model provided realistic predictions of pathogen growth during thawing of frozen ground beef and chicken.
\end{abstract}

Experts who advise consumers and regulate retail food establishments have long advised against thawing frozen raw meat and poultry items at warm temperatures. Instead, other thawing methods are recommended. For example, the U.S. Department of Agriculture (USDA) Food Safety and Inspection Service (FSIS) provides a consumer fact sheet that recommends thawing meat and poultry in the refrigerator, under cold water that is drained and replaced every $30 \mathrm{~min}$, or by heating in a microwave oven (2). Similarly, the U.S. Food and Drug Administration, in its Food Code (3), recommends that food be thawed under refrigeration. The rationale for prohibiting room-temperature thawing is that the surface of the thawing meat or poultry will reach temperatures suitable for rapid growth of bacterial pathogens. This rapid growth could presumably result in an increased risk of infection by enteric pathogens such as Salmonella and Escherichia coli O157:H7, although it is possible these organisms would be subsequently killed during proper cooking. Theoretically, it is also possible that Staphylococcus aureus would grow enough during thawing to produce dangerous amounts of heat-stable enterotoxin. Enterotoxin would not be inactivated by subsequent cooking. Although this rationale seems logical, we believe that

* Author for correspondence. Tel: 608-265-4801; Fax: 608-262-6872; E-mail: scingham@wisc.edu. room-temperature thawing of meat and poultry is probably still a widespread practice. Based on experience in monitoring pathogen growth in meat products under abusive temperatures (1) (unpublished data), we also believe that thawing typical retail portions of raw meat and poultry at room temperature is unlikely to result in significant growth of Salmonella, E. coli O157:H7, or S. aureus. In this study, we determined the time-temperature profiles at the surface of 453-g (1-lb) and 1,359-g (3-lb) portions of ground beef at comfortable $\left(22^{\circ} \mathrm{C}\right)$ and warm $\left(30^{\circ} \mathrm{C}\right)$ room temperatures during a 9-h period. An initial evaluation of the potential for pathogen growth during thawing is possible using this actual product time-temperature data and growth values from computer-generated predictive models of pathogen growth. The USDA Agricultural Research Service (ARS) has developed such models, collectively known as Pathogen Modeling Program (PMP) 7.0 (USDA-ARS, Eastern Regional Research Center, Wyndmoor, Pa.). Although the models are based on data from studies using isothermal conditions in a laboratory medium, the senior authors have frequently used these models as a primary tool in evaluating meat and poultry processing critical limits and deviations. However, computer-generated predictive models are generally not acceptable to meat and poultry regulators as the sole means of validating critical limits. Other methods, such as inoculation studies, are needed to fully validate critical limits. 
Time-temperature data were used along with microbial growth values obtained from the USDA-ARS PMP 7.0 to predict the extent of pathogen growth while thawing ground beef and whole chickens at 22 and $30^{\circ} \mathrm{C}$. Then, laboratory inoculation studies with ground beef and chicken were performed to determine the accuracy of predictions based on the PMP 7.0 values and the legitimacy of the prohibition against thawing retail portions of frozen meat and poultry at room temperature.

\section{MATERIALS AND METHODS}

Meat and poultry. Ground beef ( 85 to $95 \%$ lean) was purchased in approximately 453- and 1,359-g portions from a local grocery store, transported within $15 \mathrm{~min}$ to the laboratory, and refrigerated before use. Where the weight of portions was not 453 or $1,359 \mathrm{~g}$, small amounts of ground beef were added or removed from the portion to be used. The portion of meat was always rectangular in shape with a thickness of approximately $5 \mathrm{~cm}$. Whole chickens $(1,670 \mathrm{~g})$ were purchased from the same market, transported to the laboratory, and refrigerated. Giblets were left in the chicken body cavity.

Thawing conditions. Thawing conditions were chosen to simulate an air-conditioned room $\left(22^{\circ} \mathrm{C}\right)$ and a warm room without air conditioning $\left(30^{\circ} \mathrm{C}\right)$. The thawing time of $9.0 \mathrm{~h}$ was chosen because it simulated the time the product would thaw overnight while consumers slept and the time the product would thaw while consumers were at work during the day. An incubator was used to maintain the thawing temperature.

Determination of product temperature during thawing. Dickson model SP150 time-temperature recorders equipped with K-type thermocouple probes (Dickson Instruments, Addison, Ill.) were used to record whole chicken and ground beef temperature during thawing. For ground beef, two recorders were used, with one probe inserted in the center of the meat mass and one probe inserted just under (ca. $2 \mathrm{~mm}$ ) the upper meat surface. For whole chicken, one recorder was used, with the probe inserted just under the skin of the upper (breast) surface. Trials were conducted with $453 \mathrm{~g}$ of ground beef at 22 and $30^{\circ} \mathrm{C}, 1,359 \mathrm{~g}$ of ground beef at $30^{\circ} \mathrm{C}$, and whole chicken at $30^{\circ} \mathrm{C}$. For all trials, the chicken or ground beef was placed in a $-20^{\circ} \mathrm{C}$ freezer after the time-temperature recorder probes were inserted and held for $24 \mathrm{~h}$ before thawing at the designated temperature. The chicken was thawed with the breast surface facing up. The same temperature recording procedure was used in all trials with inoculated chicken and ground beef.

Microorganisms used in inoculation studies. Three strains each of Salmonella, E. coli O157:H7, and S. aureus were used to inoculate whole chicken and ground beef. The following $E$. coli O157:H7 strains were used: ATCC 43895 and 51657 (obtained from American Type Culture Collection, Manassas, Va.; the first strain was originally from infected patients and the second was from ground beef implicated in an outbreak) and USDA-FSIS380-94 (obtained from Dr. John Luchansky, Food Research Institute, University of Wisconsin-Madison; originally from salami implicated in an outbreak). The Salmonella serovars used were Salmonella Typhimurium S9, Salmonella Enteritidis E40, and Salmonella Heidelberg S13. All of the salmonellae were obtained from Dr. Eric Johnson, Food Research Institute, University of Wisconsin-Madison, and had been used in previous challenge studies. Strains S9 and S13 were originally isolated from samples submitted to the Wisconsin State Laboratory of Hygiene. Strain
E40 was a chicken ovary isolate. Two $S$. aureus strains, ATCC 25923 and ATCC 12600, were obtained from the American Type Culture Collection and a third strain, FRI 1007, was provided by Dr. Amy Wong (Food Research Institute, University of Wisconsin-Madison). Stock cultures were maintained at $-20^{\circ} \mathrm{C}$ in brain heart infusion broth (BHIB; Difco, Becton Dickinson, Sparks, Md.) with $10 \%$ (wt/vol) glycerol (Fisher Scientific, Itasca, Ill.) added. Working cultures, maintained at $4{ }^{\circ} \mathrm{C}$ on brain heart infusion agar (BHIA; Difco, Becton Dickinson), were prepared monthly from frozen stock cultures. To obtain a working culture, a strain was cultured twice successively at $35^{\circ} \mathrm{C}$ for 18 to $24 \mathrm{~h}$ in BHIB, streaked to a BHIA plate, incubated at $35^{\circ} \mathrm{C}$ for 18 to 24 $\mathrm{h}$ and examined for purity, and then stored at $4^{\circ} \mathrm{C}$. Inoculation cultures were prepared for each strain by transferring a colony of growth from the working culture plate to $9 \mathrm{ml}$ of BHIB and incubating at $35^{\circ} \mathrm{C}$ for 20 to $24 \mathrm{~h}$. To prepare the multispecies inoculum cocktail, each culture was centrifuged for $12 \mathrm{~min}$ at 5,000 $\times g$, the supernatant in each tube was decanted, and the pellet was resuspended in $5 \mathrm{ml}$ of Butterfield's phosphate diluent (BPD; Nelson Jameson, Marshfield, Wis.). The individual resuspended cultures were then combined in a 50-ml sterile plastic centrifuge tube, mixed, diluted in BPD, and plated (see below for description of plating and media) to determine cell concentration.

Inoculation of whole chicken and ground beef. Preliminary trials indicated that the warmest part of the whole chicken during thawing was the breast surface. In preparation for inoculating the chicken breast, a square 5.0 by $5.0 \mathrm{~cm}$ was marked with a knife to perforate the skin. Then, $0.1 \mathrm{ml}$ of inoculum was added drop-wise to the marked area and distributed using a sterile plastic spreader. After a 30-min holding period at room temperature to allow cell attachment, one inoculated chicken was analyzed and the remaining inoculated chickens were frozen at $-20^{\circ} \mathrm{C}$ for 24 h. Each trial consisted of nine chickens inoculated in this manner. Three chickens were analyzed after inoculation, three after $4.5 \mathrm{~h}$ of thawing, and three after $9 \mathrm{~h}$ of thawing. To inoculate the interior of a ground beef mass, a sanitized (70\% ethanol) knife was used to cut a slit so that the center of the mass was accessible. Then inoculum was transferred to the center of the mass and a small piece of aluminum foil (sanitized in ethanol) was placed at the inoculation spot to allow location at later sampling times. A square area 2.5 by $2.5 \mathrm{~cm}$ on the upper external surface, away from the knife slit used during internal inoculation, was also inoculated with $0.1 \mathrm{ml}$ of inoculum, which was spread over the area using a sterile plastic spreader. A small piece of sanitized aluminum foil was also used to mark this inoculation site. Each trial used nine portions of ground beef inoculated in this manner. After a 30-min attachment period, three inoculated ground beef portions were analyzed; the remaining masses were frozen at $-20^{\circ} \mathrm{C}$ for $24 \mathrm{~h}$, and then three portions each were analyzed after 4.5 and 9 $\mathrm{h}$ of thawing.

Enumeration of inoculum organisms. Numbers of inoculum organisms on thawing chicken were analyzed after 4.5 and 9 $\mathrm{h}$ of thawing (different chickens for each sampling time). The sample was obtained by excising the inoculated area of 5.0 by 5.0 $\mathrm{cm}$. Similarly, an area 2.5 by $2.5 \mathrm{~cm}$ around the foil marker was excised from the interior and exterior of ground beef after 4.5 and $9 \mathrm{~h}$ of thawing. The thickness of excised chicken and ground beef samples was approximately $1.2 \mathrm{~cm}$, resulting in samples that weighed 15 to $20 \mathrm{~g}$. Each excised sample was placed in a stomacher filter bag, $99 \mathrm{ml}$ of BPD was added, and the sample was pummeled for $30 \mathrm{~s}$ at medium speed in a Stomacher 400 lab blender (Fisher Scientific). Subsequent dilutions were made in $\mathrm{BPD}$, and spread plates were prepared (one plate per dilution) on 
sorbitol MacConkey agar (Oxoid, Inc., Ogdensburg, N.Y.) and XLD agar (Oxoid) for enumeration of E. coli O157:H7 and Salmonella serovars, respectively. Plates were incubated at $35^{\circ} \mathrm{C}$ for $24 \mathrm{~h}$, typical colonies (white or colorless on sorbitol MacConkey agar and black on XLD) were counted and log CFU per piece was calculated. Enumeration of $S$. aureus was performed by preparing 3M Petrifilm Staph Express plates (3M Microbiology, St. Paul, Minn.). The 3M Petrifilm Staph Express plates were incubated at $35^{\circ} \mathrm{C}$ for $24 \mathrm{~h}$. Only red-to-purple colonies were observed on a plate after $24 \mathrm{~h}$; these were counted as presumptive $S$. aureus, and the thermonuclease disk analysis was not necessary. For each inoculum species, one presumptive colony per trial was selected for confirmation. The selected colonies were grown on BHIA for $24 \mathrm{~h}$ at $35^{\circ} \mathrm{C}$ and then tested as follows. Presumptive E. coli O157: $\mathrm{H} 7$ isolates were tested for Gram reaction, cellular morphology, oxidase reaction, production of typical colonies on Levine's EMB agar (Difco, Becton Dickinson), and presence of O157 antigen (DrySpot latex agglutination kit, Oxoid). Presumptive Salmonella serovar isolates were tested for Gram reaction, cellular morphology, oxidase reaction, and biochemical profile (API 20E, bioMérieux, Hazelwood, Mo.). Presumptive $S$. aureus isolates were evaluated for Gram reaction, cellular morphology, and catalase reaction. Throughout the study, the identity of all presumptive isolates was confirmed.

Data analysis. For each combination of product type, product size, and thawing temperature, three independent trials were conducted. For each trial, there were three chickens or three portions of ground beef analyzed at each sampling time. For each inoculum organism, the mean log CFU per sample was calculated for the trial and then the mean and standard deviation for the change in log CFU per sample over three trials was calculated.

Prediction of growth using values from the PMP 7.0 model. For each $5.5^{\circ} \mathrm{C}\left(10^{\circ} \mathrm{F}\right)$ product temperature interval during thawing, the growth values from the PMP 7.0 predictive growth model were used to predict whether Salmonella serovars, E. coli O157:H7, and $S$. aureus lag phase would be completed and, if it was completed, the number of generations of pathogen growth that would occur. To obtain the lag phase and generation times, the following environmental conditions were used in the model: aerobic growth for the surface of ground beef and whole chicken, anaerobic growth for the ground beef interior, $\mathrm{pH} 6.5,0.5 \%$ waterphase sodium chloride, and no added sodium nitrite. No model was available for anaerobic growth of Salmonella serovars, so no prediction was made for Salmonella growth in the interior of the ground beef portions. Each temperature interval was below the optimum temperature for growth of a given pathogen, so the maximum temperature for the interval was assumed to have occurred for the entire interval. For example, if the temperature interval was 5 to $10^{\circ} \mathrm{C}$, then the temperature of $10^{\circ} \mathrm{C}$ was assumed to have occurred for the entire interval. It was assumed that the pathogens were initially in lag phase (plausible since the cells had been frozen) and that the lag time at each given temperature during thawing was the same as for the corresponding temperature during an isothermal experiment. Based on these assumptions, the proportion of lag phase elapsing during each temperature interval was calculated from the model values and the cumulative proportion of lag phase was calculated. Similarly, if the entire lag phase had elapsed, the number of growth generations predicted during each temperature interval was determined from the corresponding isothermal model information and the cumulative number of growth generations was calculated.

\section{RESULTS AND DISCUSSION}

After $9 \mathrm{~h}$ of thawing at $30^{\circ} \mathrm{C}$, the exterior of the whole chickens had reached a temperature of $20^{\circ} \mathrm{C}$. This temperature is well below the optimum for rapid pathogen growth. As expected, no pathogen growth was predicted when whole-chicken time-temperature data were analyzed using values from the PMP 7.0 model (Table 1). Inoculation studies showed no evidence of pathogen growth (Table 2) and thus the predictions based on PMP 7.0 values were accurate.

These results strongly suggest that thawing a chicken of this size at $\leq 30^{\circ} \mathrm{C}$ for up to $9 \mathrm{~h}$ is a safe procedure. By extension, thawing a larger chicken with these time-temperature limitations should also be safe. However, the following practices cannot be recommended based on the results of this study: (i) thawing a smaller chicken with these time-temperature limits, (ii) thawing any size chicken at a temperature $>30^{\circ} \mathrm{C}$, or (iii) thawing any size chicken for $>9 \mathrm{~h}$.

The exterior of the 453- and 1,359-g portions of ground beef had reached 27 and $11^{\circ} \mathrm{C}$ during $30^{\circ} \mathrm{C}$ thawing, and the exterior temperature of the $453 \mathrm{-g}$ portions of ground beef reached $17^{\circ} \mathrm{C}$ during $22^{\circ} \mathrm{C}$ thawing. Slight growth of $E$. coli $\mathrm{O} 157: \mathrm{H} 7$ (0.2 to 2.7 generations) and $S$. aureus (3.1 to 5.0 generations) was predicted for the exterior of the $453 \mathrm{-g}$ portion of ground beef thawed at $30^{\circ} \mathrm{C}$. This predicted growth was between a 0.04- and 1.2-log CFU increase. Similarly, slight growth of E. coli O157:H7 (0.1 to 1.9 generations) and $S$. aureus (0 to 1.3 generations) was predicted for the interior of the $453 \mathrm{-g}$ portion of ground beef thawed at $30^{\circ} \mathrm{C}$. No growth of any pathogen was predicted for the interior or exterior of $453 \mathrm{-g}$ portions of ground beef thawed at $22^{\circ} \mathrm{C}$ or for $1,359-\mathrm{g}$ portions thawed at $30^{\circ} \mathrm{C}$. Ground beef inoculation studies showed that the predictions were conservative (i.e., predicted more growth than actually occurred) for the exterior and interior of the $453 \mathrm{-g}$ ground beef portions thawed at $30^{\circ} \mathrm{C}$. Inoculation study results for $453-\mathrm{g}$ portions thawed at $22^{\circ} \mathrm{C}$ and 1,359 g portions thawed at $30^{\circ} \mathrm{C}$ were consistent with predictions. The greatest increase in pathogen numbers, relative to prefreezing levels, was 0.4 to $0.5 \mathrm{log}$ on the exterior of the $453-\mathrm{g}$ ground beef portions thawed at 22 and $30^{\circ} \mathrm{C}$. All other trials showed little or no increase in pathogen numbers relative to prefreezing values. Comparison of pathogen levels after 4.5 and $9 \mathrm{~h}$ of thawing clearly showed that pathogen growth was occurring on the 453-g ground beef portion exterior surface at $30^{\circ} \mathrm{C}$.

The results of ground beef thawing experiments strongly suggest that thawing $\geq 453$ g of ground beef portions at $\leq 22^{\circ} \mathrm{C}$ for $\leq 9 \mathrm{~h}$ is not a particularly hazardous practice. Thawing ground beef portions of $\geq 1,359 \mathrm{~g}$ at $\leq 30^{\circ} \mathrm{C}$ for $\leq 9 \mathrm{~h}$ also appears unlikely to be hazardous. However, thawing small portions ( $\leq 453 \mathrm{~g}$ ) of ground beef at 22 or $30^{\circ} \mathrm{C}$ for $9 \mathrm{~h}$ or thawing any size portion of ground beef for $>9 \mathrm{~h}$ cannot be recommended based on our findings.

In summary, room-temperature thawing of relatively large whole chickens or ground beef portions for a period of $\leq 9 \mathrm{~h}$ is highly unlikely to result in an increased risk of foodborne illness associated with Salmonella serovars, E. 
TABLE 1. Growth of Escherichia coli O157:H7, Salmonella serovars, and Staphylococcus aureus predicted from values obtained from the USDA ARS PMP 7.0 model applied to time-temperature conditions for thawing of whole chickens and ground beef at 22 or $30^{\circ} \mathrm{C}$

\begin{tabular}{|c|c|c|c|c|c|c|}
\hline \multirow[b]{2}{*}{ Product and size } & \multirow{2}{*}{$\begin{array}{c}\text { Thaw } \\
\text { temperature } \\
\left({ }^{\circ} \mathrm{C}\right)\end{array}$} & \multirow{2}{*}{$\begin{array}{l}\text { Location } \\
\text { of probe }\end{array}$} & \multicolumn{2}{|c|}{ Temperature $\left({ }^{\circ} \mathrm{C}\right)^{a}$} & \multirow[b]{2}{*}{ Organism } & \multirow{2}{*}{$\begin{array}{l}\text { Predicted growth } \\
\quad \text { (generations) }^{b}\end{array}$} \\
\hline & & & After $4.5 \mathrm{~h}$ & After $9 \mathrm{~h}$ & & \\
\hline \multirow[t]{3}{*}{ Chicken, 1,670 g } & 30 & Exterior & $9(2.0)$ & $20(0.6)$ & Salmonella & $0,0,0$ \\
\hline & & & & & E. coli & $0,0,0$ \\
\hline & & & & & S. aureus & $0,0,0$ \\
\hline \multirow{10}{*}{ Ground beef, $453 \mathrm{~g}$} & 22 & Interior & $-1.5(n=2)$ & $17(n=2)$ & E. coli & 0,0 \\
\hline & & & & & S. aureus & 0,0 \\
\hline & & Exterior & $2(n=2)$ & $17(n=2)$ & Salmonella & 0,0 \\
\hline & & & & & E. coli & 0,0 \\
\hline & & & & & S. aureus & 0,0 \\
\hline & 30 & Interior & $-0.7(0.6)$ & $27(0.6)$ & E. coli & $1.9,0.1,0.1$ \\
\hline & & & & & S. aureus & $1.3,0,0.4$ \\
\hline & & Exterior & $4(2.0)$ & $27(0.6)$ & Salmonella & $0,0,0$ \\
\hline & & & & & E. coli & $2.7,0.2,0.9$ \\
\hline & & & & & S. aureus & $5.0,3.3,3.1$ \\
\hline \multirow[t]{5}{*}{ Ground beef, 1,359 g } & 30 & Interior & $-1(0.6)$ & $9(1.1)$ & E. coli & $0,0,0$ \\
\hline & & & & & S. aureus & $0,0,0$ \\
\hline & & Exterior & $2.3(4.0)$ & $11(3.1)$ & Salmonella & $0,0,0$ \\
\hline & & & & & E. coli & $0,0,0$ \\
\hline & & & & & S. aureus & $0,0,0$ \\
\hline
\end{tabular}

${ }^{a}$ Mean of three values, unless otherwise indicated. Standard deviation is in parentheses.

${ }^{b}$ Each value is from data obtained in a single trial.

TABLE 2. Observed growth of Escherichia coli O157:H7, Salmonella serovars, and Staphylococcus aureus during thawing of whole chickens and ground beef at 22 or $30^{\circ} \mathrm{C}$

\begin{tabular}{|c|c|c|c|c|c|}
\hline \multirow[b]{2}{*}{ Product and size } & \multirow{2}{*}{$\begin{array}{l}\text { Thaw } \\
\text { temperature } \\
\left({ }^{\circ} \mathrm{C}\right)\end{array}$} & \multirow{2}{*}{$\begin{array}{l}\text { Location } \\
\text { of probe }\end{array}$} & \multirow[b]{2}{*}{ Organism } & \multicolumn{2}{|c|}{ Change in $\log \mathrm{CFU}^{a}$} \\
\hline & & & & After $4.5 \mathrm{~h}$ & After $9 \mathrm{~h}$ \\
\hline \multirow[t]{3}{*}{ Chicken, $1,670.5 \mathrm{~g}$} & 30 & Exterior & Salmonella & $-0.6(0.5)$ & $-0.6(0.5)$ \\
\hline & & & E. coli & $-0.4(0.3)$ & $-0.9(0.4)$ \\
\hline & & & S. aureus & $-0.1(0.3)$ & $-0.4(0.5)$ \\
\hline \multirow[t]{12}{*}{ Ground beef, $453 \mathrm{~g}$} & 22 & Interior & Salmonella & $-0.5(n=2)$ & -0.2 \\
\hline & & & E. coli & $0(n=2)$ & +0.1 \\
\hline & & & S. aureus & $0.2(n=2)$ & 0 \\
\hline & & Exterior & Salmonella & $-0.2(n=2)$ & -0.1 \\
\hline & & & E. coli & $0.1(n=2)$ & 0.1 \\
\hline & & & S. aureus & $0.3(n=2)$ & 0.5 \\
\hline & 30 & Interior & Salmonella & $-0.2(0.2)$ & $0(0.1)$ \\
\hline & & & E. coli & $0(0)$ & $0.1(0.1)$ \\
\hline & & & S. aureus & $0.1(0.1)$ & $-0.1(0.2)$ \\
\hline & & Exterior & Salmonella & $-0.1(0.1)$ & $0.4(0.3)$ \\
\hline & & & E. coli & $-0.1(0.1)$ & $0.4(0.4)$ \\
\hline & & & S. aureus & $0.2(0.1)$ & $0.2(0.1)$ \\
\hline \multirow{6}{*}{ Ground beef, $1,359 \mathrm{~g}$} & 30 & Interior & Salmonella & NT & $-0.1(0.3)$ \\
\hline & & & E. coli & NT & $-0.1(0.1)$ \\
\hline & & & S. aureus & NT & $-0.1(0.2)$ \\
\hline & & Exterior & Salmonella & NT & $0(0.1)$ \\
\hline & & & E. coli & NT & $-0.1(0.1)$ \\
\hline & & & S. aureus & NT & $0(0.2)$ \\
\hline
\end{tabular}

${ }^{a}$ Relative to value for time 0 (before freezing); value is mean of two or three trials. When three trials were conducted, the standard deviation is shown in parentheses. No standard deviation is shown for conditions tested in two trials. NT, not tested. 
coli $\mathrm{O} 157: \mathrm{H7}$, or S. aureus. Guidance for consumers and retail food establishments is clearly conservative and perhaps could be revised.

\section{REFERENCES}

1. Ingham, S. C., J. A. Losinski, and K. L. Becker. 2004. Growth of Escherichia coli $\mathrm{O} 157: \mathrm{H} 7$ and Salmonella serovars on raw beef, pork, chicken, bratwurst and cured corned beef: implications for HACCP plan critical limits. J. Food Saf. 24:246-256.

2. U.S. Department of Agriculture. 2004. The big thaw: safe defrosting methods for consumers. Available at: http://www.fsis.usda.gov/ factsheets/big_thaw/index.asp. Accessed 9 November 2004.

3. U.S. Department of Health and Human Services, Public Health Service, Food and Drug Administration. 2004. 2001 Food Code. Available at: http://www.cfsan.fda.gov/ dms/fc01-3.html. Accessed 9 November 2004. 